\title{
Resistance of Alkali-Activated Slag Concrete to Chloride-Induced Corrosion
}

\author{
Joon Woo Park, ${ }^{1}$ Ki Yong Ann, ${ }^{1}$ and Chang-Geun Cho ${ }^{2}$ \\ ${ }^{1}$ Department of Civil and Environmental Engineering, Hanyang University, Ansan 426, Republic of Korea
}

${ }^{2}$ School of Architecture, Chosun University, Gwangju 501, Republic of Korea

Correspondence should be addressed to Chang-Geun Cho; chocg@chosun.ac.kr

Received 28 April 2015; Revised 5 August 2015; Accepted 6 August 2015

Academic Editor: Antônio G. B. de Lima

Copyright (C) 2015 Joon Woo Park et al. This is an open access article distributed under the Creative Commons Attribution License, which permits unrestricted use, distribution, and reproduction in any medium, provided the original work is properly cited.

The corrosion resistance of steel in alkali-activated slag (AAS) mortar was evaluated by a monitoring of the galvanic current and halfcell potential with time against a chloride-contaminated environment. For chloride transport, rapid chloride penetration test was performed, and chloride binding capacity of AAS was evaluated at a given chloride. The mortar/paste specimens were manufactured with ground granulated blast-furnace slag, instead of Portland cement, and alkali activators were added in mixing water, including $\mathrm{Ca}(\mathrm{OH})_{2}, \mathrm{KOH}$ and $\mathrm{NaOH}$, to activate hydration process. As a result, it was found that the corrosion behavior was strongly dependent on the type of alkali activator: the AAS containing the $\mathrm{Ca}(\mathrm{OH})_{2}$ activator was the most passive in monitoring of the galvanic corrosion and half-cell potential, while $\mathrm{KOH}$, and $\mathrm{NaOH}$ activators indicated a similar level of corrosion to Portland cement mortar (control). Despite a lower binding of chloride ions in the paste, the AAS had quite a higher resistance to chloride transport in rapid chloride penetration, presumably due to the lower level of capillary pores, which was ensured by the pore distribution of AAS mortar in mercury intrusion porosimetry.

\section{Introduction}

Reducing the $\mathrm{CO}_{2}$ emission in cement industry has achieved an increasing attention for the last several decades, due to a large margin of $\mathrm{CO}_{2}$ emitted in process of producing ordinary Portland cement, accounting for about $800-1000 \mathrm{~kg} / \mathrm{ton}$ cement [1]. Thus, a mixture with noncarbon emitting binder, for example, ground granulated blast-furnace slag (GGBS) and pulverized fuel ash (PFA), has been used in a concrete mix. However, when it comes to the global warming impact, GGBS and PFA have adversely increased allocation to the warming impact rather than Portland cement [2]. Despite debates on pozzolanic materials and their environmental impact, the pozzolanic materials have been thoroughly studied as noncarbon emitting materials [3-5]. As these pozzolanic materials can moreover enhance properties of concrete, their replacement was limited by a very low hydraulic reactivity. For example, the replacement with GGBS has been often in the range of $40-60 \%$ to binder and $20-$ $30 \%$ for PFA. Thomas studied PFA concrete resulting in better protection to steel due to its increased resistance to chloride ion penetration [6]. The GGBS concrete had the lowest level of the apparent diffusion coefficient compared to OPC concrete as discussed by Ryou and Ann [7]. To increase a portion of carbon-free binder, a chemical activator must seemingly be accompanied. Representatively, alkali-based chemical activators have been used to enhance hydraulic reaction in the matrix of pozzolanic binder, which had shown that a rapid development of concrete strength was achieved by a formation of dense C-S-H gel, in particular, GGBS concrete, so-called alkali-activated slag (AAS). The use of AAS combined with various activators has been currently reported about their properties in particular a development of strength in the majority of previous studies [8-11].

Despite increased strength of concrete, properties of AAS concrete are still subjected to debate. For AAS concrete to apply for a structural material in concrete structures, its compatibility with concrete properties must be ensured. In particular, AAS concrete is intuitively suspected to a lower resistance to chloride-induced corrosion of steel embedment, because the alkalinity of AAS is relatively lower compared to Portland cement; the corrosion resistance of steel embedment 
TABLE 1: Oxide composition of GGBS and OPC.

\begin{tabular}{lcccccccc}
\hline Binder type & \multicolumn{4}{c}{ Oxide composition $(\%)$} & \multicolumn{2}{c}{$\begin{array}{c}\text { Ignition loss } \\
(\%)\end{array}$} \\
& $\mathrm{CaO}$ & $\mathrm{SiO}_{2}$ & $\mathrm{Al}_{2} \mathrm{O}_{3}$ & $\mathrm{FeO}$ & $\mathrm{MgO}$ & $\mathrm{SO}_{3}$ & $\begin{array}{c}\text { Fineness } \\
\left(\mathrm{cm}^{2} / \mathrm{g}\right)\end{array}$ \\
\hline OPC & 60.0 & 23.0 & 5.0 & 2.0 & 1.0 & 2.0 & 2.1 & 3120 \\
GGBS & 41.2 & 34.2 & 11.7 & 1.4 & 3.7 & 1.7 & 1.29 & 4290 \\
\hline
\end{tabular}

TABLE 2: Mix proportion for AAS mortar and control specimens.

\begin{tabular}{|c|c|c|c|c|c|c|c|c|}
\hline & \multirow{2}{*}{$\mathrm{W} / \mathrm{B}$} & \multirow{2}{*}{$\begin{array}{c}\text { OPC } \\
\left(\mathrm{kg} / \mathrm{m}^{3}\right)\end{array}$} & \multirow{2}{*}{$\begin{array}{c}\text { GGBS } \\
\left(\mathrm{kg} / \mathrm{m}^{3}\right)\end{array}$} & \multirow{2}{*}{$\begin{array}{l}\text { Water } \\
\left(\mathrm{kg} / \mathrm{m}^{3}\right)\end{array}$} & \multicolumn{3}{|c|}{ Activator $\left(\mathrm{kg} / \mathrm{m}^{3}\right)$} & \multirow{2}{*}{$\begin{array}{c}\text { Sand } \\
\left(\mathrm{kg} / \mathrm{m}^{3}\right)\end{array}$} \\
\hline & & & & & $\mathrm{KOH}$ & $\mathrm{NaOH}$ & $\mathrm{Ca}(\mathrm{OH})_{2}$ & \\
\hline Control & 0.40 & 581.6 & - & 232.7 & - & - & - & 1425.0 \\
\hline \multirow{3}{*}{ AAS } & 0.40 & - & 569.6 & 227.8 & 28.1 & - & - & 1395.5 \\
\hline & 0.40 & - & 569.6 & 220.8 & - & 20.1 & - & 1395.5 \\
\hline & 0.40 & - & 569.6 & 220.8 & - & - & 18.6 & 1395.5 \\
\hline
\end{tabular}

is usually determined by the alkalinity of pore solution, as the steel is protected by the passive film on the surface formed in a very alkaline environment as discussed by Ann and Song [12]. Moreover, a reduction of the alkalinity of the pore solution could lead to less binding of chlorides, and in turn more free chlorides can increase the corrosiveness. When it comes to ionic transport, AAS concrete may be susceptible to external ionic percolation at a given time for curing of concrete, as a lower degree of hydration in the AAS matrix may produce an open pore structure, which would substantially form further hydration products in a latent hydration.

In this study, GGBS was used as an AAS. To activate the chemical reaction in terms of hydration process, alkali-based chemical activators (i.e., $\mathrm{KOH}, \mathrm{NaOH}$, and $\mathrm{Ca}(\mathrm{OH})_{2}$ ) were admixed in mixing water. To evaluate the resistance of AAS to chloride-induced corrosion, the galvanic current of steel in chloride-contaminated AAS mortar was monitored. For ionic transport, rapid chloride penetration was examined, and chloride binding capacity was determined at a given chloride cast in paste specimens.

\section{Experimental Works}

2.1. Specimen Preparation. To assess the corrosion resistance of alkali-activated slag (AAS) concrete, ground granulated blast-furnace slag (GGBS) was used as a binder, while ordinary Portland cement (OPC) was simultaneously used to produce control specimens. The oxide composition of binders which was measured by the X-ray fluorescence analysis is given in Table 1 . The specific gravity of GGBS and OPC was 2.84 and 3.15, respectively. To activate the hydration process in the GGBS matrix, alkali activators were admixed in mixing water, including $\mathrm{KOH}, \mathrm{NaOH}$, and $\mathrm{Ca}(\mathrm{OH})_{2}$. The activator content was determined by $\mathrm{OH}^{-}$ion concentration in the mixing solution.

AAS mortar specimens were cast for a measurement of the pore volume, chloride permeability, and corrosion behavior. Three different activators were added in the variation of $\mathrm{OH}^{-}$ion concentration. Mix proportion for binder, water, and sand was $1.00: 0.40: 2.45$ as given in Table 2 . For chloride binding capacity, paste specimen was cast, assuming that aggregate has no chemical reactivity in concrete.

2.2. Chemistry at Chlorides in AAS. For testing of chloride binding capacity, AAS paste was cast in a mould $(20 \times 20 \times 20 \mathrm{~mm})$ at 0.4 of $\mathrm{W} / \mathrm{B}$. Five levels of chloride ions were admixed in the form of $\mathrm{NaCl}$, ranging from 0.5 to $3.0 \%$ by weight of binder. After demoulding, the samples were wrapped in a polythene film and cured at $25 \pm 1^{\circ} \mathrm{C}$ to avoid leaching out of hydroxyl and chloride ion from AAS paste. After 90 days of curing, the specimens were dried in the oven at $50^{\circ} \mathrm{C}$ for 48 hours to remove the pore water in the matrix and avoid a chemical change in matrix. The powder sample was obtained by crushing, grinding, and sieving with a $300 \mu \mathrm{m}$ sieve. Then the powder sample was placed in a beaker with $50 \mathrm{~mL}$ at $50^{\circ} \mathrm{C}$ distilled water. The samples were stirred for $5 \mathrm{~min}$ and stood for $30 \mathrm{~min}$ to extract chloride ions. Then, the samples were filtered through the filter paper to measure concentration of water-soluble chloride ions, of which information can be used to determine the chloride binding capacity at a concentration of total chloride.

The X-ray diffraction (XRD) analysis was used to characterize hydration products and bound chloride in the AAS paste. After 90 days of curing, the specimens were dried in the oven at $50^{\circ} \mathrm{C}$ for 48 hours to remove the pore water in the paste. Then the powder sample obtained was used for XRD analysis, which was conducted by a device D/MAX RINT 2000 with an analyzing range $(2 \theta): 5-70^{\circ}$; scan rate: $4^{\circ} / \mathrm{min}$; voltage: $40 \mathrm{kV}$; current density: $100 \mathrm{~mA}$; tube target: $\mathrm{Cu}$; and wave length: $1.5405 \AA(\mathrm{Cu} / \mathrm{K}-\alpha 1)$, respectively.

2.3. Ionic Permeability. Rapid chloride ion penetrability test was performed to evaluate the ionic transport in AAS mortar. This test procedure was well explained elsewhere [13]. In present study, the mortar specimen was used to minimize the influence of gravel, rather than concrete. The AAS cylindrical mortar $(\varnothing 100 \times 50 \mathrm{~mm})$ was connected to two chambers for an electric circuit as shown in Figure 1: one was filled with $0.3 \mathrm{M}$ sodium hydroxide and the other with $3 \%$ sodium chloride. Mesh electrode was connected to a DC supplier in 


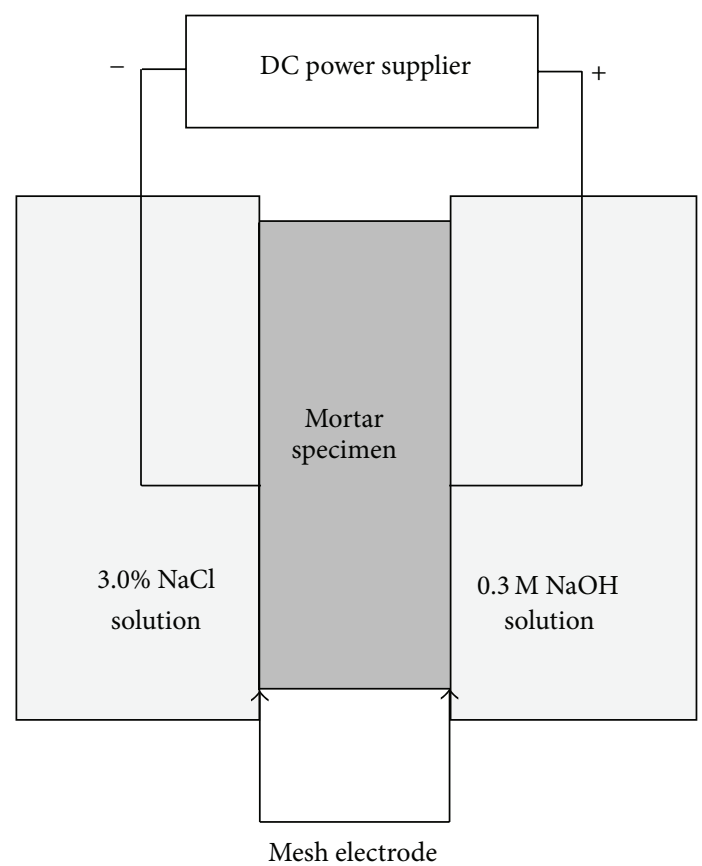

FIGURE 1: Set-up for rapid chloride ion penetration test.

condition of $60 \mathrm{~V}$ for 6 hours. The current flowing through the mortar specimen was monitored every 30 minutes. Then, the total current passed was calculated to determine the permeability. Thus, the higher level of charge passed indicated the higher ionic transport in terms of penetrability permeability. Its advised guideline is given in Table 3 .

The mercury intrusion porosimetry (MIP) was used to investigate the pore distribution and pore volume of the AAS paste. A fragment was obtained from the middle of the paste specimen, followed by the drying process at $50^{\circ} \mathrm{C}$ for 48 hours. Then the sample was placed in a glass tube filled with mercury. The sample was subsequently imposed by mercury filling pressure ranging from $3.7 \times 10^{-3}$ to $413.7 \mathrm{MPa}$, so that the mercury intrusion volume was recorded at a corresponding pressure. The pore diameter was derived from the pressure using the Washburn equation as given in

$$
d=\frac{-4 \gamma \cos \theta}{P}
$$

where $d$ is the pore diameter $(\mu \mathrm{m}) ; \gamma$ is the surface tension (dynes $/ \mathrm{cm}) ; P$ is the pressure ( $\mathrm{MPa}$ ); and $\theta$ is the contact angle $\left({ }^{\circ}\right)$ in which the present study took this value as $130^{\circ}$.

\subsection{Corrosion Monitoring. To assess the corrosion resistance} of AAS, the galvanic current and half-cell potential of the steel in AAS mortar were monitored. AAS mortar was cast with a centrally located steel rebar. The specimen was subjected to a wet and dry cyclic condition (3 days wet and 4 days dry), and $1.5 \%$ of chlorides were admixed in mixing water to accelerate the steel corrosion. The current flowing between the embedded steel and the titanium mesh was monitored by measuring the potential drop across a $10 \mathrm{k} \Omega$ resistor, as shown in Figure 2. The galvanic current was measured twice
TABLE 3: Chloride ion penetrability based on charge passed for concrete specimen [9].

\begin{tabular}{lc}
\hline $\begin{array}{l}\text { Charge passed } \\
\text { (coulombs) }\end{array}$ & Chloride ion penetrability \\
\hline 4000 & High \\
$2000-4000$ & Moderate \\
$1000-2000$ & Low \\
$100-1000$ & Very low \\
$<100$ & Negligible \\
\hline
\end{tabular}

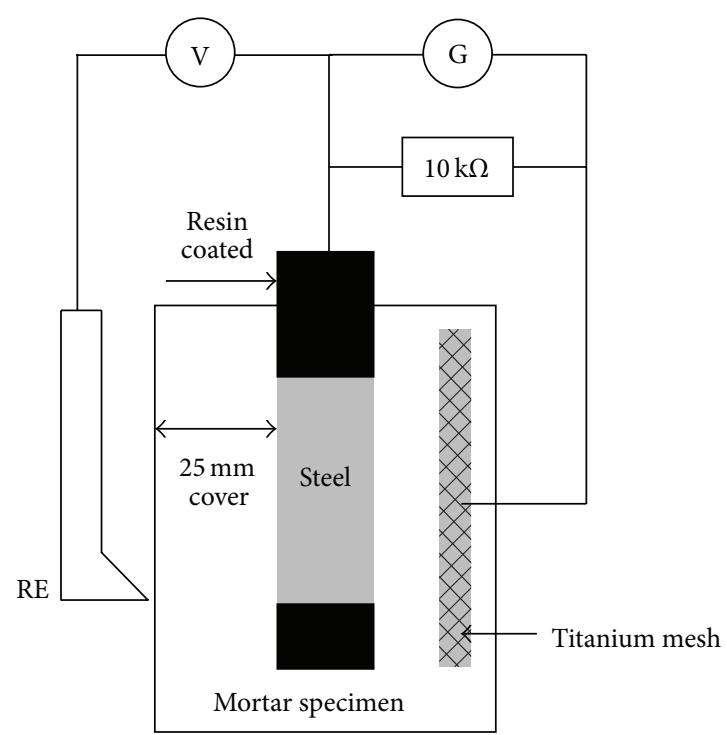

FIGURE 2: Set-up for galvanic and half-cell monitoring of steel in mortar.

a week until 25 weeks. Simultaneously half-cell potential was measured using a standard calomel electrode.

\section{Results and Discussion}

3.1. Binding of Chlorides in AAS Matrix. As both free and bound chlorides are simultaneously present in the pore solution and cement matrix, one of them must be defined to binding capacity of chloride ions at a given total chloride. In this study, concentration of free chlorides in AAS paste was measured by the water extraction method for a given total chloride, which was subsequently used to render the binding capacity. Figure 3 gives the relation between free and bound chlorides by using the equation form of the Langmuir isotherm, as shown in

$$
C_{\text {bound }}=\frac{\alpha C_{\text {free }}}{1+\beta C_{\text {free }}},
$$

where $C_{\text {bound }}$ is the concentration of bound chloride; $C_{\text {free }}$ is the concentration of free chloride; and $\alpha$ and $\beta$ are constants. For control (Portland cement paste), half of chlorides were mostly bound at a lower level of total chlorides. Then, it is evident that an increase in the total chloride concentration resulted in an increase in the bound chlorides. However, 


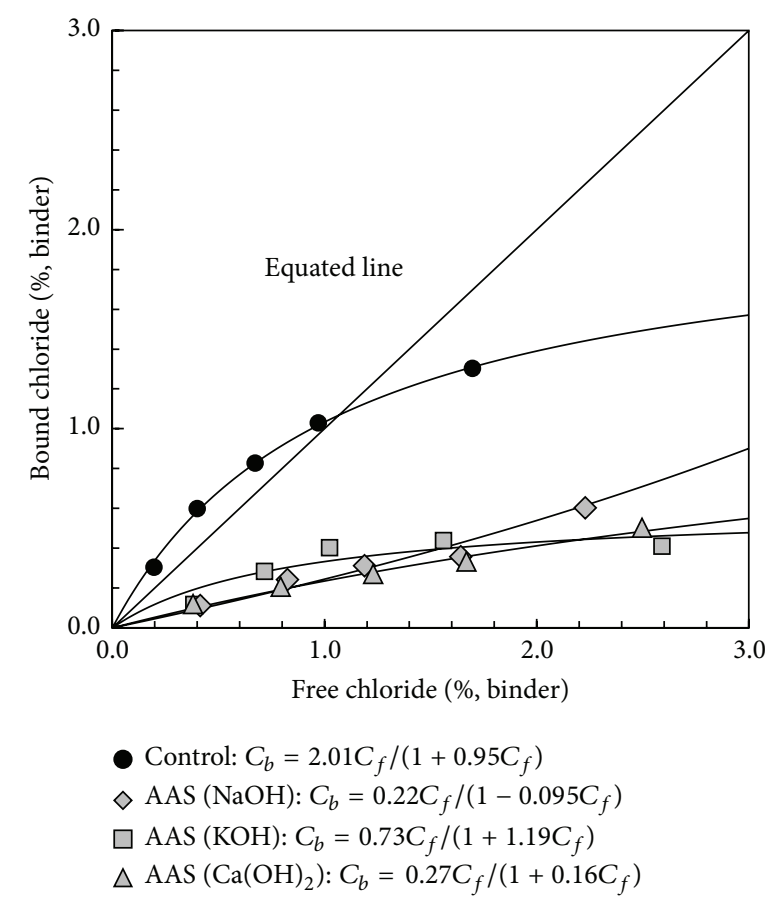

FIGURE 3: Langmuir isotherms between free and bound chlorides depending on activator type.

the ratio of bound chloride chlorides to total was adversely reduced, presumably due to limited binding capacity of Portland cement paste. It is seen that the chloride binding capacity for AAS was significantly lower than for Portland cement paste. At a given total chloride concentration, even higher levels of free chloride were present in the cement paste. This may be attributed to a marginal concentration of $\mathrm{C}_{3} \mathrm{~A}$ in AAS. Glass and Buenfeld [14] showed that binding capacity of chloride ions was strongly dependent on the content of $\mathrm{C}_{3} \mathrm{~A}$ in cement clinker, which is reactive with chlorides to form the crystallized Friedel's salt (i.e., bound chlorides). The role of chloride binding at steel corrosion in concrete is subjected to debate. For example, Kim et al. [15] suggested that there was no clear-cut relation between chloride binding and corrosion risk on the stage of corrosion initiation, although the rate of corrosion propagation might be affected by concentration of free chlorides, in turn binding capacity of chlorides. Glass et al. [16] support this hypothesis that no influence of chloride binding on the corrosion risk is given, as the bound chloride chlorides could be released to be free in the vicinity of steel due to a $\mathrm{pH}$ fall from the electrochemistry on the steel surface. However, in a number of previous studies, an increase in the chloride binding in terms of $\mathrm{C}_{3} \mathrm{~A}$ resulted in an increase in the corrosiveness, determined by the corrosion rate, potential, and even visual examination [14]. Hydration products, for example, C-S-H gel and precipitated $\mathrm{Ca}(\mathrm{OH})_{2}$, may bind chloride ions in the cement matrix. Unlike $\mathrm{C}_{3} \mathrm{~A}$ binding of chlorides, hydration products can adsorb chloride ions on the surface of hydrates layer, which may therefore be released into free or/and mobile ones at a diluted condition.

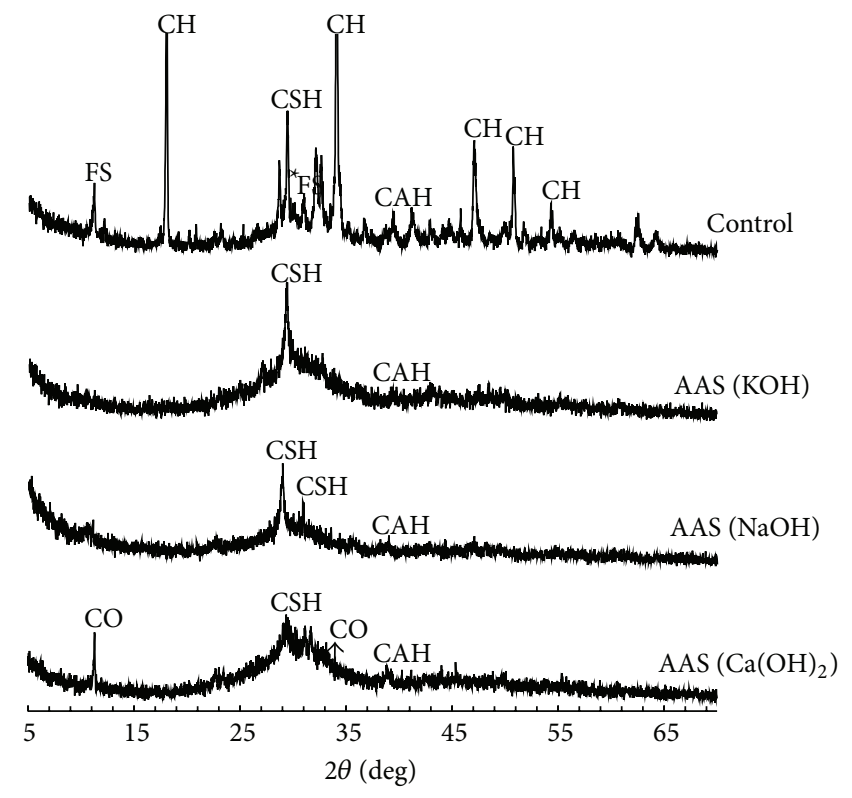

$\begin{array}{ll}\text { CH: portlandite } & \text { CSH: C-S-H phase } \\ \text { FS: Friedel's salt } & \text { CAH: C-A-H phase } \\ \text { CO: calcium oxychloride } & \end{array}$

FIgURE 4: XRD curves for AAS paste admixed with 1.5\% chlorides.

To observe chloride binding at chemistry, the XRD for AAS paste containing $1.5 \%$ of chloride was analysed as seen in Figure 4. Irrespective of the alkali activator, it seems that the C-S-H gel was mainly produced together with $\mathrm{C}-\mathrm{A}-\mathrm{H}$ as hydration products at a low $\mathrm{Ca} / \mathrm{Si}$ ratio, while portlandite and C-S-H gel were mainly produced in Portland cement paste. In Portland cement paste, Friedel's salt $\left(3 \mathrm{CaO} \cdot \mathrm{Al}_{2} \mathrm{O}_{3} \cdot \mathrm{CaCl}_{2} \cdot 10 \mathrm{H}_{2} \mathrm{O}\right)$ was often observed at different locations, and in turn chlorides were much bound presumably by $\mathrm{C}_{3} \mathrm{~A}$ and $\mathrm{C}_{4} \mathrm{AF}$ [17-19]. However, in AAS paste, only C-S-H gel and C-A-H were formed, implying that chlorides could be less bound. In AAS paste containing the $\mathrm{Ca}(\mathrm{OH})_{2}$ activator, in particular, calcium oxychloride $\left(\mathrm{Ca}(\mathrm{ClO})_{2}\right)$ was formed. It may suggest that $\mathrm{Ca}(\mathrm{OH})_{2}$ might have reacted with chlorides, seemingly physical adsorption. Precipitated $\mathrm{Ca}(\mathrm{OH})_{2}$ can usually adsorb chloride ions by physically surrounding chloride ions in the matrix and then remove free chlorides, of which adsorbed chlorides may be subsequently dissolved in acidic solution. This binding of chlorides is substantially attributed to the presence of precipitated $\mathrm{Ca}(\mathrm{OH})_{2}$, which was presumably provided by the activator. Thus, it can be said that the $\mathrm{Ca}(\mathrm{OH})_{2}$ activator may enhance chloride binding capacity and thus the resistance to chloride-induced corrosion.

3.2. Ionic Permeability and Pore Structure. The current passed through the AAS cell for 6 hours is given in Figure 5, together with converted value of charge. The ionic penetrability of 


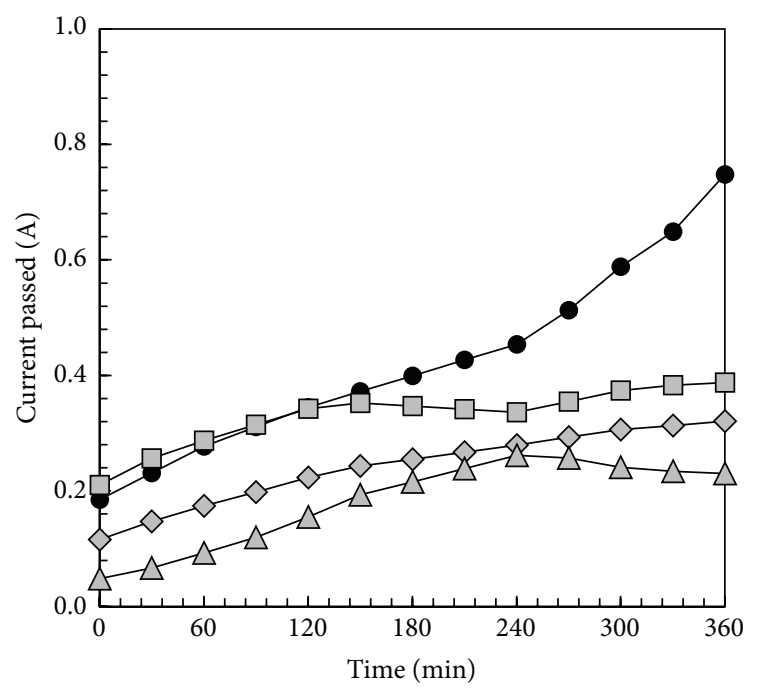

Total charge passed

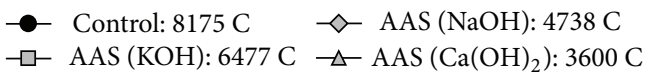

FIGURE 5: Charged current with time depending on activator type.

the control specimen had the highest current and charge, accounting for $8175 \mathrm{C}$, while the charge passed for AAS specimens ranged from 3600 to $6477 \mathrm{C}$. A reduction of the charge passed, in terms of ionic transport, in AAS mortar may result from a denser pore structure arising from GGBS, which was finely further grained to admix in concrete and then to block ionic paths in the specimens [20]. Moreover, the AAS mortar containing the $\mathrm{Ca}(\mathrm{OH})_{2}$ activator produced the greatest resistance to ionic transport, which may be attributed to precipitation of $\mathrm{Ca}(\mathrm{OH})_{2}$ in the cement matrix. Formation of precipitated $\mathrm{Ca}(\mathrm{OH})_{2}$ could lead to a further hydration, socalled a latent hydration, and thus the pore structure might be modified to denser one. When it comes to the guided values for the ionic transport, all specimens were ranked in "moderate," due to the absence of gravel in the specimen, which would otherwise form an electric barrier and then reduce the charge passed through the cell.

The pore structure examined by the mercury intrusion porosimetry is given in Figure 6, in terms of cumulative pore volume with the decreasing pore diameter. It is evident that the pore volume and pore distribution are dependent of binder and the activator. For control specimen, the total pore volume was equated to $0.102 \mathrm{~mL} / \mathrm{g}$ and $0.121-0.137 \mathrm{~mL} / \mathrm{g}$ for AAS specimens. The high level of pore volume for AAS specimens is ascribed to a sharp increase in the gel pores $(<0.01 \mu \mathrm{m})$, which might have been mainly formed in the C$\mathrm{S}-\mathrm{H}$ gel [21-23]. However, this range of pores is not open to ionic transport; ions and molecules are mobile only in the range of capillary pores. Thus, it can be said that a reduced value of the charge passed for AAS specimen could be achieved by a modified pore structure, encompassing the lower level of capillary pore and higher gel pore. Notwithstanding, the porosity converted from the pore distribution

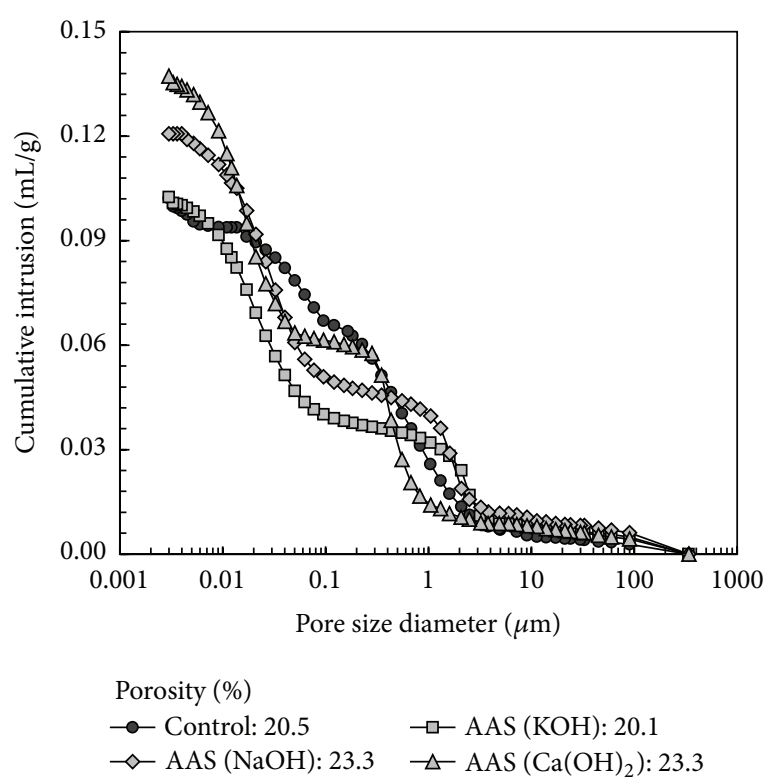

FIGURE 6: Cumulative intrusion of AAS and control mortars.

was always in the similar range, irrespective of binder and activator, accounting for $20.1-23.3 \%$.

3.3. Resistance to Chloride-Induced Corrosion. To assess the corrosion resistance of AAS, the galvanic current of steel in AAS mortar was monitored for 25 weeks, subjected to a wet and dry cyclic condition to accelerate the corrosion process. The obtained galvanic current for AAS is given in Figure 7. It is evident that the galvanic current was sharply increased to high at the state of corrosion, whilst an even lower value was kept at the passive state. For control, the galvanic current was jumped to $10 \mathrm{~mA} / \mathrm{mm}^{2}$ or beyond at 13 weeks, indicating the onset of corrosion. However, the steel in AAS mortar containing the $\mathrm{KOH}$ and $\mathrm{NaOH}$ activators was presumed to be corrosive after 5 weeks, of which the galvanic current was significantly increased to $15-25 \mathrm{~mA} / \mathrm{mm}^{2}$, implying the lower corrosion resistance, compared to Portland cement concrete. However, in AAS containing the $\mathrm{Ca}(\mathrm{OH})_{2}$ activator, the galvanic current was always mostly nullified for 25 weeks, as being passive to corrosion. Again, the higher corrosion resistance of AAS with the $\mathrm{Ca}(\mathrm{OH})_{2}$ activator is attributed to precipitated $\mathrm{Ca}(\mathrm{OH})_{2}$, which could enhance the capacity of chloride binding at chloride adsorption to remove from the pore solution and then to mitigate the corrosion risk.

Simultaneously, half-cell potential was monitored for an equated duration, as given in Figure 8. Considering the critical potential for the corrosion initiation (i.e., $-275 \mathrm{mV}$ versus SCE), the passivity of steel in AAS containing the $\mathrm{Ca}(\mathrm{OH})_{2}$ activator was again confirmed. For the first 1012 weeks, the half-cell potential was much fluctuated for all specimens, due to the high sensitivity of electrode to the concrete resistivity. Then, propagation of the half-cell potential was clearly different from the binder and activator in AAS mortars. For control specimen, the half-cell potential was dramatically decreased, after 12 weeks, to the corrosive 


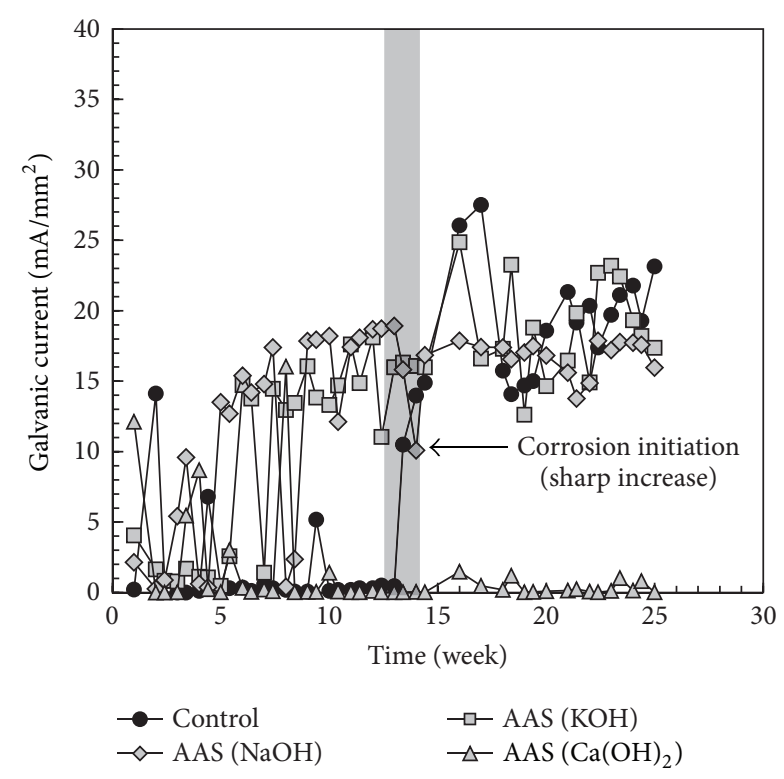

FIGURE 7: Monitoring of galvanic currents of steel in AAS mortar.

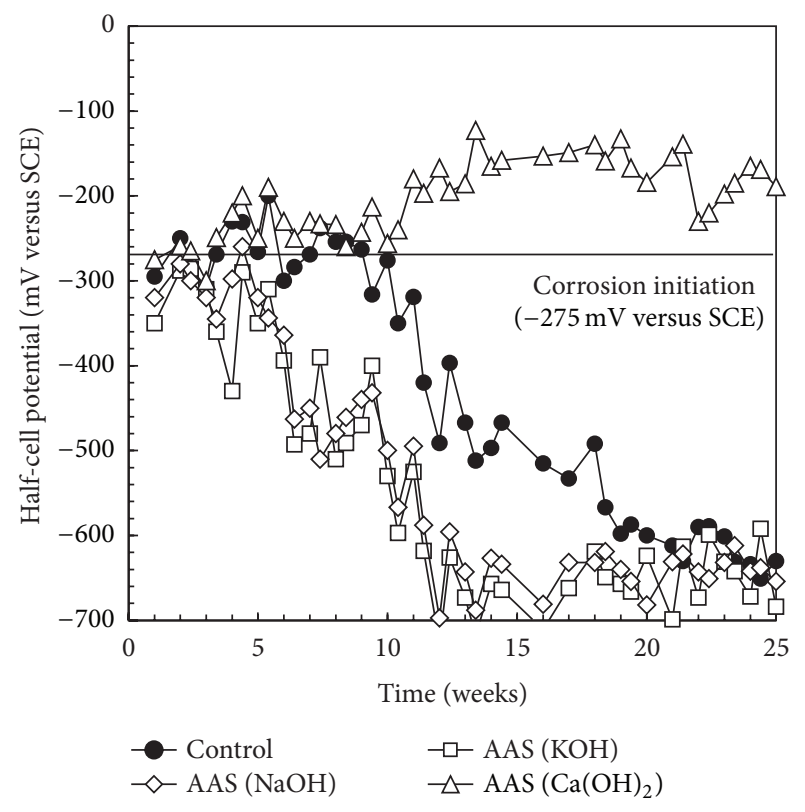

FIGURE 8: Monitoring of half-cell potential of steel in AAS mortar.

state, while the AAS containing $\mathrm{KOH}$ and $\mathrm{NaOH}$ activators indicated the corrosive state mostly from the beginning of monitoring. Again the AAS containing the $\mathrm{Ca}(\mathrm{OH})_{2}$ activator showed the highest half-cell potential, indicating no corrosion formation. Substantially, it can be said that the AAS can be beneficial with the $\mathrm{Ca}(\mathrm{OH})_{2}$ activator against chloride-induced corrosion, arising from increased binding of chlorides in the form of $\mathrm{Ca}(\mathrm{ClO})_{2}$ and modified pore structure.

\section{Conclusion}

In this study, the corrosion resistance of steel embedment in AAS mortar was assessed by a monitoring of the galvanic current and half-cell potential in chloride-contaminated AAS mortar. To ensure the chemistry of chlorides in AAS, chloride binding was determined by the water extraction method and formation of chlorides in the AAS matrix was confirmed by the XRD analysis. Finally, the pore structure and ionic transport were examined by the rapid chloride penetrability test and mercury porosimetry. The conclusion derived from the experimental works is as follows:

(1) The corrosion resistance of AAS was strongly dependent on the activator. For $\mathrm{KOH}$ and $\mathrm{NaOH}$, the corrosion behavior was mostly similar to Portland cement mortar, but the $\mathrm{Ca}(\mathrm{OH})_{2}$ activator increased the corrosion resistance; the galvanic current always indicated the passive state for 25 weeks and simultaneously the half-cell potential exceeded the threshold voltage for the onset of corrosion $(-275 \mathrm{mV}$ versus SCE).

(2) The higher resistance of AAS containing the $\mathrm{Ca}(\mathrm{OH})_{2}$ activator to chloride-induced corrosion may be attributed to precipitation of $\mathrm{Ca}(\mathrm{OH})_{2}$ in the matrix, which might have reacted with chlorides to physically form $\mathrm{Ca}(\mathrm{ClO})_{2}$ to remove free chlorides from the pore solution, although the binding capacity of chlorides was lower than for Portland cement paste. However, AAS containing the $\mathrm{KOH}$ and $\mathrm{NaOH}$ activators had no benefit in binding chlorides in the cement matrix.

(3) The AAS mortar had a higher resistance to ionic transport in testing of rapid chloride penetrability test, presumably due to the use of finely grained GGBS, which may fill up the voids in concrete/mortar. Moreover, a modification of the pore structure may reduce the openness to external ions and molecules: in fact, the capillary pores were reduced and the gel pore was increased.

\section{Conflict of Interests}

The authors declare that there is no conflict of interests regarding the publication of this paper.

\section{Acknowledgments}

This research was supported by the National Research Foundation of Korea (NRF) funded by the Ministry of Education, Science and Technology (Grant no. 2012R1A1A1014432) and supported by a Grant 14RDRP-B076268 from Regional Development Research Program funded by the Ministry of Land, Infrastructures, and Transport of Korean Government.

\section{References}

[1] H. S. Lee, " $\mathrm{LCCO}_{2}$ assessment of concrete and $\mathrm{CO}_{2}$ reducing technology," in Concrete and Environment, pp. 180-199, Korea Concrete Institute, 2010. 
[2] G. Habert, J. B. D’Espinose De Lacaillerie, E. Lanta, and N. Roussel, "Environmental evaluation for cement substitution with geopolymers," in Proceedings of the 2nd International Conference on Sustainable Construction Materials and Technologies, pp. 1607-1615, Ancona, Italy, June 2010.

[3] F. Puertas, A. Fernández-Jiménez, and M. T. Blanco-Varela, "Pore solution in alkali-activated slag cement pastes. Relation to the composition and structure of calcium silicate hydrate," Cement and Concrete Research, vol. 34, no. 1, pp. 139-148, 2004.

[4] E. Douglas, A. Bilodeau, J. Brandstetr, and V. M. Malhotra, "Alkali activated ground granulated blast-furnace slag concrete: preliminary investigation," Cement and Concrete Research, vol. 21, no. 1, pp. 101-108, 1991.

[5] C. Shi and R. L. Day, "A calorimetric study of early hydration of alkali-slag cements," Cement and Concrete Research, vol. 25, no. 6, pp. 1333-1346, 1995.

[6] M. Thomas, "Chloride thresholds in marine concrete," Cement and Concrete Research, vol. 26, no. 4, pp. 513-519, 1996.

[7] J. S. Ryou and K. Y. Ann, "Variation in the chloride threshold level for steel corrosion in concrete arising from different chloride sources," Magazine of Concrete Research, vol. 60, no. 3, pp. 177-187, 2008.

[8] N. G. Lim, S. W. Jeong, J. W. Her, and K. Y. Ann, "Properties of cement-free concrete cast by finely grained nanoslag with the $\mathrm{NaOH}$-based alkali activator," Construction and Building Materials, vol. 35, pp. 557-563, 2012.

[9] K. Y. Ann, J. H. Kim, and S. Y. Song, "Development of cementfree concrete using finely grained slag for Portland cement," Applied Mechanics and Materials, vol. 316-317, pp. 1063-1070, 2013.

[10] C. Shi, "Strength, pore structure and permeability of alkaliactivated slag mortars," Cement and Concrete Research, vol. 26, no. 12, pp. 1789-1799, 1996.

[11] A. R. Brough and A. Atkinson, "Sodium silicate-based, alkaliactivated slag mortars part I. Strength, hydration and microstructure," Cement and Concrete Research, vol. 32, no. 6, pp. 865879, 2002.

[12] K. Y. Ann and H.-W. Song, "Chloride threshold level for corrosion of steel in concrete," Corrosion Science, vol. 49, no. 11, pp. 4113-4133, 2007.

[13] ASTM C 1202-91, "Standard test method for electrical indication of concrete's ability to resist chloride ion penetration," 1991.

[14] G. K. Glass and N. R. Buenfeld, "The influence of chloride binding on the chloride induced corrosion risk in reinforced concrete," Corrosion Science, vol. 42, no. 2, pp. 329-344, 2000.

[15] D. G. Kim, H. J. Lee, and K. Y. Ann, "Semi-quantitative prediction of the corrosion risk of steel in concrete using XRD analysis," Journal of Advanced Concrete Technology, vol. 9, no. 3, pp. 231-239, 2011.

[16] G. K. Glass, B. Reddy, and N. R. Buenfeld, "The participation of bound chloride in passive film breakdown on steel in concrete," Corrosion Science, vol. 42, no. 11, pp. 2013-2021, 2000.

[17] A. M. Neville, "Binding of chloride ions," in Properties of Concrete, chapter 11, pp. 569-571, John Wiley \& Sons, 4th edition, 1996.

[18] K. Y. Ann, H. W. Song, C. H. Lee, and M. S. Jung, "Chloride binding capacity of cementitious materials and its influence on concrete structures," in Proceedings of the 5th International Conference on Concrete under Severe Conditions: Environment and Loading (CONSEC '07), pp. 351-360, Tours, France, June 2007.
[19] C. Arya, N. R. Buenfeld, and J. B. Newman, "Factors influencing chloride-binding in concrete," Cement and Concrete Research, vol. 20, no. 2, pp. 291-300, 1990.

[20] K. Y. Ann, H. Y. Moon, Y. B. Kim, and J. Ryou, "Durability of recycled aggregate concrete using pozzolanic materials," Waste Management, vol. 28, no. 6, pp. 993-999, 2008.

[21] S. Zhang and M. Zhang, "Hydration of cement and pore structure of concrete cured in tropical environment," Cement and Concrete Research, vol. 36, no. 10, pp. 1947-1953, 2006.

[22] G. Ye, Experimental study and numerical simulation of the development of the microstructure and permeability of cementitious materials [Ph.D. thesis], Delft University and Technology, Delft, The Netherlands, 2003.

[23] T. Yamaguchi, K. Negishi, S. Hoshino, and T. Tanaka, "Modeling of diffusive mass transport in micropores in cement based materials," Cement and Concrete Research, vol. 39, no. 12, pp. 1149-1155, 2009. 

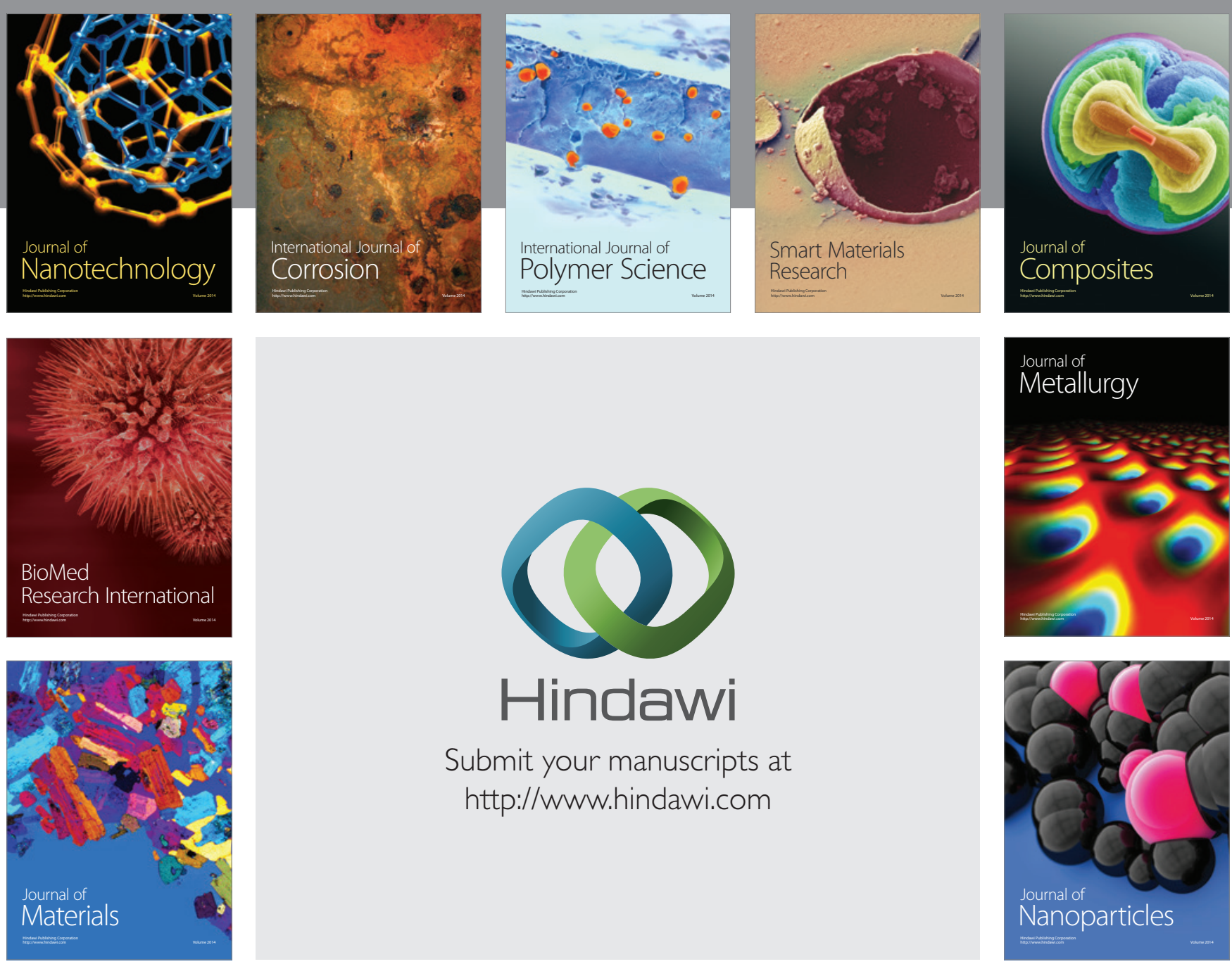

Submit your manuscripts at http://www.hindawi.com
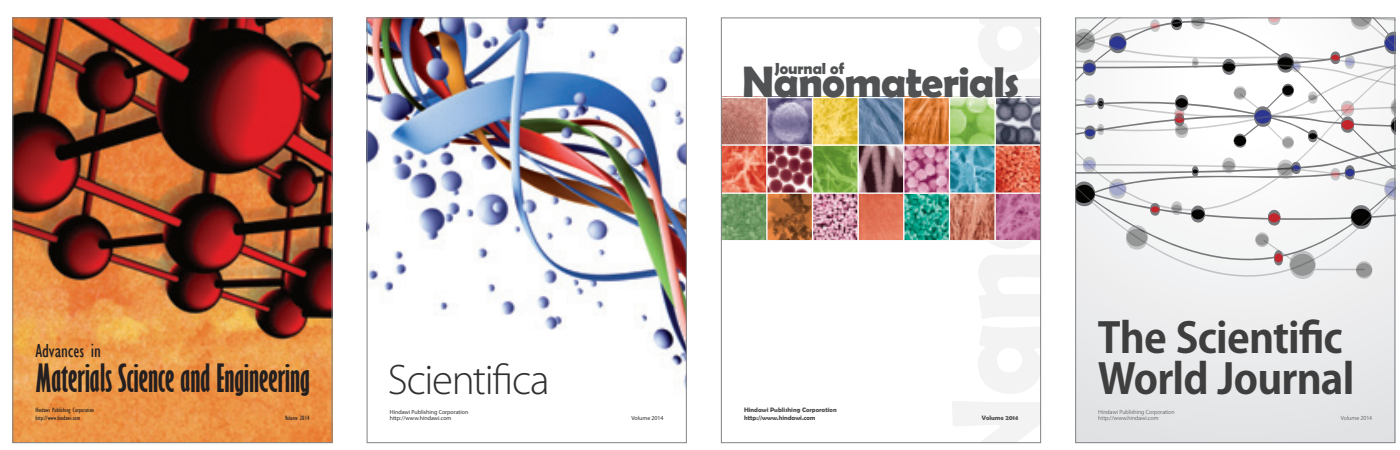

\section{The Scientific World Journal}
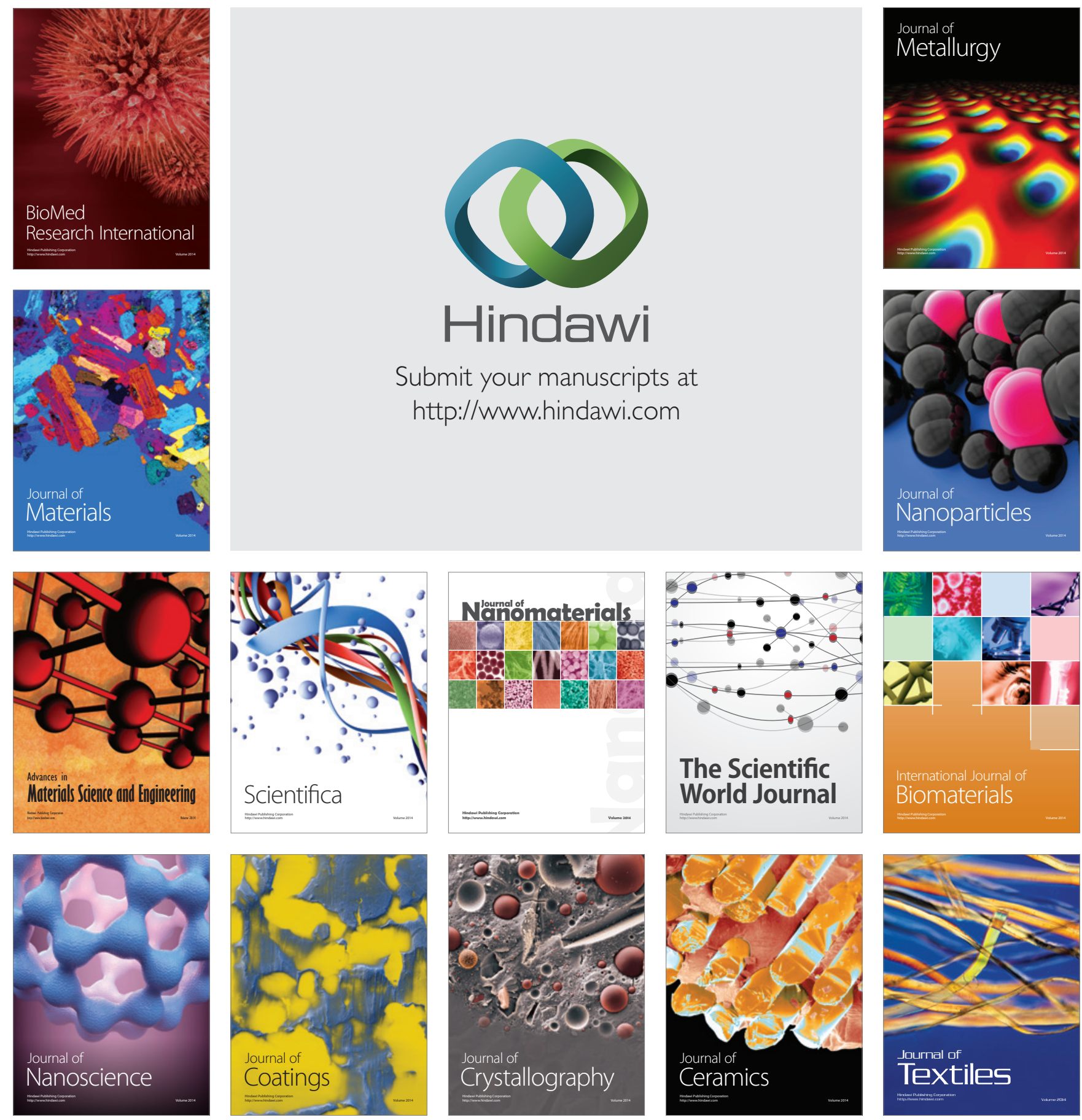